\title{
О.В. Черничкина
}

Волгоградский государственный соџиальный педагогический университет

\section{Инициирующие коммуникативные ходы в супружеском дискурсе}

Аннотация: Статья посвящена теме коммуникативной инициативы в супружеском общении. Автор предлагает свою классификацию типов инициирующих коммуникативных ходов по различным критериям: по характеру коммуникативно-прагматических высказываний, по характеру совершаемого речевого действия и по характеру речевого воздействия. Каждый тип подробно рассмотрен на материале, взятом из кинофильмов, художественной литературы и картотеки записей устной речи (КЗУР).

This article is devoted to the theme of communicative initiative in the matrimonial communication. The author provides the classification of initiative communicative actions, according to the different criteria: based on the sort of communicative and pragmatic statements, based on the sort of committed speech act and based on the sort of the impact produced. Each type is thoroughly studied and described on the basis of the following material: films, literature and transcriptions of everyday oral speech.

Ключевые слова: коммуникативная инициатива, супружеский дискурс, инициирующий коммуникативный ход, коммуникативная стратегия.

Communicative initiative, matrimonial discourse, communicative initiative action, communicative strategies.

УДК: 81-42.

Контактная информащия: Волгоград, пр. Ленина, 23. ВГСПУ, филологический факультет. Тел. (906) 1727636. E-mail: oxana.chernichkina@gmail.com.

Рассматривая проявления инициативы в супружеском общении, мы выбрали в качестве объекта нашего исследования коммуникативную ситуацию. Однако любая коммуникативная ситуация предполагает вербальные и невербальные действия коммуникантов, развивающие интеракцию, т. е. коммуникативные ходы партнеров по общению [Леонтович, 2011, с. 209]. Коммуникативный ход постулируется в качестве минимально значимого компонента интеракции, что предполагает не только вербальную экспликацию интенции говорящего, но и ее невербальное сопровождение и развивает, по словам М.Л. Макарова, взаимодействие участников диалога в соответствии с целевой доминантой [Макаров, 2003, с. 183].

Цель данной статьи - уточнение понятия «инициирующий коммуникативный ход», а также описание возможных типов инициирующих коммуникативных ходов.

Коммуникативная инициатива - это один из основных составляющих элементов речевого воздействия, интегративная часть диалогического общения, предполагающая введение темы интеракции. Однако следует подчеркнуть, что понятие коммуникативной инициативы не сводится только к непосредственной инициации общения, к первой инициальной реплике. Например, этикетные формулы, используемые в начале диалога для установления контакта партнеров, не

(c) О.В. Черничкина 
свидетельствуют о владении коммуникативной инициативой в общении. Не вызывает сомнения тот факт, что «гораздо чаще адресант начинает процесс общения с того, что представляется ему интересным или актуальным на данный момент» [Бобырева, 1996, с. 8], и поэтому взятие инициативы как зачин диалога оказывается наиболее частым случаем ее проявления. Однако, как справедливо указывает М.Л. Макаров, участник, который владеет коммуникативной инициативой, - это необязательно автор первой реплики [Макаров, 2003, с. 218], из этого следует признание нетождественности инициальной реплики и инициирующего коммуникативного хода. Под инициальной репликой, по мнению Е.В. Бобыревой, следует понимать любое высказывание одного из участников процесса общения, открывающее диалогический текст, ограниченное одним речевым ходом партнера по коммуникации, выражающее определенную коммуникативную интенцию и преследующее определенную иллокутивную цель [Бобырева, 1996, с. 11]. В качестве наиболее часто реализуемой иллокутивной цели инициальной реплики выступает установление контакта, это может осуществляться определенными вербальными сигналами (например: Привет, как дела?).

Однако взятие инициативы в общении не ограничивается выполнением только контактоустанавливающей функции. В процессе диалогической интеракции можно наблюдать проявление коммуникативной инициативы собеседниками и в середине диалога, что является маркером его политемности. В этом случае целесообразным оказывается говорить об инициирующей, а не инициальной реплике, а точнее, инициирующем коммуникативном ходе, поскольку, как убедительно доказывает М.Л. Макаров, опираясь на положения зарубежных лингвистов, реплики не могут быть инициативными и реактивными [Wunderlich, 1976] (цит. по: [Макаров, 2003, с. 184]). Это качество принадлежит только коммуникативному ходу и обусловлено его функциональной направленностью [Roulet, 1992] (цит. по: [Макаров, 2003, с. 184]), а именно, нацеленностью на развитие диалогического взаимодействия.

Взятие инициативы в общении мы считаем одной из разновидностей коммуникативных ходов. Именно коммуникативный ход, по мнению О.С. Иссерс, является основным приемом, который выступает «в качестве инструмента реализации той или иной речевой тактики» [Иссерс, 2006, с. 153]. Мы будем рассматривать инициирующий коммуникативный ход как тактический прием речевой деятельности, направленный на введение интересующей инициатора - коммуниканта темы общения, предполагающий реализацию определенной коммуникативной стратегической цели. Допускаем, что характер и типы инициирующих коммуникативных ходов определяются личностью инициатора общения, его коммуникативной интенцией и дискурсом, в формате которого проходит интеракция, а также конкретной ситуацией общения.

Анализ теоретических исследований, прямо или косвенно связанных с проблемой типизации коммуникативных ходов, а также собранный нами корпус примеров супружеского общения, включающий фрагменты художественной коммуникации, кинематографии и картотеку записи устной речи (КЗУР), позволяют сделать вывод о возможности различных подходов к классификации инициирующих коммуникативных ходов по разным критериям.

I. В зависимости от характера коммуникативнопрагматических высказываний, т.е. на основании синтаксического критерия, можно выделить следующие типы коммуникативных ходов, эксплицирующих инициативу со стороны адресанта:

1. Инициирующий вопрос:

- О чем ты все время думаешь? - Я? - Ть - А ты о чем? - Я о тебе! -И я-о тебе... Башмаков почеловал Вету и вздохнул про себя: "Бедный ребенок, она еще верит в то, что лежащие в одной постели мужчина и женщина могут объяс- 
нить друг другу, о чем они на самом деле думают!» - A почему ты вздыхаешь? Поживешь с моё... (Ю. Поляков. Замыслил я побег);

2. Утверждение-сообщение как введение новой информации:

Зоя: Ты совсем не занимаешься ребенком. Такое впечатление, что тебе все равно.

Игнатий: Что ты хочешь?

Зоя: Я хочу, чтобы ты обратил внимание на своего сына и на себя самого. Tы совсем перестал готовиться к конкурсу. Кончится тем, что ты опять провалишься и останешься преподавателем чтения хоровых партитур. (В. Токарева. Розовые розы);

3. Императив как побуждение к действию, в форме приказа, совета, просьбы

- Гостей покличь, Харитина. Всех зови: бригадиров, прораба, Якова Прокопыча, родню любезную. Зови всех: Егор Полушкин мир угощать желает. (Б. Васильев. Не стреляйте в белых лебедей);

4. Риторический вопрос, не требующий ответа и не предполагающий дальнейшего взаимодействия. Мы считаем возможным выделить данную разновидность коммуникативного хода отдельно, учитывая тот факт, что речевая форма выражения инициативы в общении не всегда может иметь адекватную интерпретацию. Например, фразу «Когда же ты прекратишь издеваться надо мной?» вряд ли можно рассматривать как инициирующий вопрос, требующий ответа, это скорее упрек, выражение эмоционального состояния коммуниканта

- Ты долго там будешь пилить? Насмешил людей, а теперь спать им не даешь. Кретин! Тебя же счас во всех квартирах обсуждают! (В. Шукшин. Жена мужа в Париж провожала).

В данном случае этот вопрос интерпретируется как завуалированный приказ замолчать. Такая разновидность ходов, по нашему мнению, может заключать в себе как императив, так и сообщение, например: Рассказать тебе о Москве? (что предполагает нарративное продолжение без получения возможной обратной связи).

II. К типизации инициирующих коммуникативных ходов можно подойти, отталкиваясь от характера совериаемого речевого действия, выделяя констатативные, регулятивные, экспрессивные, декларативные и др. ходы, сигнализирующие о взятии и сохранении инициативы в общении.

III. Однако более значимым критерием для выделения и описания типов инициирующих ходов выступает, на наш взгляд, коммуникативная интенция инициатора общения, обусловленная характером речевого воздействия. Л.Л. Федорова отмечает, что цель общения инициатора диалога задает стратегию, а конкретные иллокутивные цели обоих собеседников в каждом речевом акте обусловливают тактику ведения диалога [Федорова, 2007, с. 103-135]. Следовательно, характер предполагаемого и реализуемого речевого воздействия также может обусловливать и классификацию типов инициирующих ходов. Речевое воздействие - это способ оказания влияния на сознание и коммуникативное поведение партнера по общению. С помощью речи человек побуждает своего собеседника начать, изменить, закончить какую-либо деятельность, влияет на принимаемые им решения, изменяет его картину мира [Иссерс, 2006]. Учитывая тип предполагаемого речевого воздействия (информирование, разъяснение, волеизъявление, социальные, оценочные и эмоциональные воздействия и др.), что, по нашему мнению, отражает интенционально-функциональный аспект проявления инициативы, мы считаем возможным выделить следующие типы инициирующих коммуникативных ходов:

1. Контакто-устанавливающий ход, что отражает с одной стороны социальное воздействие этикетно-фатического характера и в этом случае, как нам видится, зачастую совпадает с инициальной репликой, а с другой стороны, настраивает собеседника на одну «коммуникативную волну», снимая возможные коммуника- 
тивные преграды. В качестве наиболее частотного случая подобной инициативы рассмотрим кинотекст, реконструирующий сцену знакомства:

Парень: Девушка! Девушка, а можно с вами познакомиться?

Девушка: Нет, нельзя.

Парень: А почему?

Девушка: Ну потому что я на улице не знакомлюсь.

Парень: И совершенно верно. Знакомиться на улице - это легкомыслие, это дурной тон, и я бы даже сказал пошлость. Ох, какие у вас глаза лучистые, девушка! Как вас зовут, $a ?$ ? (К/ф «Прогулка»).

Преследуемая цель коммуникативного хода парня - познакомиться - реализуется сначала через прямой вопрос (можно с вами познакомиться), уточняющий вопрос (а почему), подстраивание под партнера через одобрение его отказа от общения (совершенно верно), комплимент (какие у вас глаза лучистые) и, наконец, возвращение к исходному вопросу о знакомстве (как вас зовут).

2. Эмоционально-экспрессивнылй инициирующий ход, внутри разновидности которого можно выделить как эмоционально-возвыщающий (настрой собеседника на одну волну, оказание эмоциональной поддержки, эмоциональное «поглаживание»), так и эмоционально-уничижительный подтипы, когда выплеск эмоций, а иногда и притворная эмоциональная индифферентность имеют цель причинить «эмоциональную боль» партнеру или выразить свои чувства по отношению к нему. Рассмотрим следующий пример из произведения Е. Колиной «Личное дело Кати К.»:

- А у Димы по утрам всегда ЛИЦО. И ещуе он по утрам всегда вздыххает, очень громко, я бы сказала, настойчиво вздыхает. И я каждое утро пугаюсь, что у него за время ночного отдыха случилось что-то непоправимое. - Что с тобой? - Я вилась вокруг Димы, как щенок. - Что, что, что? Устал ... - вздохнул он. - Ть же только что проснулся... - намекнула я. - Ну и что? - непонимающе сказал Дима и вздохнул еще громче.

Данная фраза «что с тобой?», по сути, не является вопросом, а идентифицируется как попытка эмоционально зарядить партнера и одновременно выразить свое беспокойство по поводу его состояния и настроения, демонстрируя свою любовь и заботу. Достаточно часто, особенно в бытовом дискурсе, смена эмоционального градуса происходит так стремительно, что трудно выделить переходный момент. Так, следующий пример наглядно демонстрирует динамическую смену «эмоционального тонуса» у инициатора общения, в данном случае это женщина.

Она. Ты посредственность. Ничтожная посредственность!

Он. Замолчи сейчас же!

Она (рыдая). Уходи! Уходи!.. (Она постепенно успокаивается, но, еще всхлипывая, подходит и молча обнимает его.)

Он. Что же это?

Она. Молчи... Почелуй меня... Еще... (Нежно.) Ты почему на меня кричал?

Он. Это ты кричала на меня.

Она. Мне можно, я женщина. Поцелуй меня... ещче.. Ты никогда не будешь на меня кричать так гадко? Ну еще... Ты меня любишь? (Э. Радзинский. Монологи о браке).

Динамика эмоционального состояния проявляется со всей очевидностью: от первого инициирующего хода оскорбления до выражения просьбы поцеловать ее, что подкрепляется и невербальными средствами: от криков до интонационной нежности и объятий.

3. Информационно-ориентирующий ход в контексте инициативы в общении предполагает передачу сообщения или получения информации от партнера с помощью определенных ориентиров, как правило, в качестве таких ориентиров выступают наводящие вопросы: 
Галина. Слушай, слушай, что я тебе скажу.

Зилов. $H y$.

Галина. Я хочу ребенка.

Зилов. Опять?

Галина. Пора нам с тобой, сльщшишь?

Зилов. Tbl думаешь?

Галина. Никогда я его так не хотела... A тыз Что ты на это скажешь? (А. Вампилов. Утиная охота).

В данном примере жена достаточно робко, с помощью перформатива «слушай, что я тебе скажу» вводит новую информацию о ее желании иметь ребенка и пытается с помощью вопросов выяснить отношение мужа к данной перспективе.

4. Оценочный инициирующий ход. Высказанная оценка событий, действий или личностных качеств человека может послужить темой обсуждения, вводимой инициатором общения:

Себейкин. Вот бог бабу-то послал! У других, замечаю, когда деньги в доме, то и баба золото, прямо вся такая живая и сделается! А уж как деньгам конеи, тут и начинается! А моя!.. Ей что так, что не так!.. Нет, все!.. Где это костюм мой был?.

Клава. Ну ладно, ладно! (Удерживает его.) (М. Рощин. Старый новый год).

Несмотря на то, что диалог имеет место между героем и его родственником, оценочное суждение Себейкина имплицитно адресовано жене как объекту оценки.

5. Директивно-прескриптивный инищиирующий ход (явная форма - приказ, неявная - совет). Рассмотрим это на примере диалога супругов из романа Ю. Полякова «Возвращение блудного мужа»:

- В ванной полно грязных рубашек, - сказала она.

- Да, хорошо бы постирать... - согласился он.

- Конечно! Но сначала надо их обязательно замочить, а воротники и манжеты натереть порошком...

- Haтереть?

- Да, натереть. А ты не знал? Показать?

- Нет, Инночка, я сам...

- Ах, ты мой самостоятельный, все сам... Все сам! - она засмеялась и нежно укусила его за ухо.

В данном диалоге сочетаются информативность («в ванной полно грязных рубашек»), модальность («сначала надо...), постановка вопроса («А ты не знал?), предложение помощи («Показать?»), оценочность («Ах, ты мой самостоятельный, все сам») и эмоциональность коммуникативного хода, эксплицируемая невербально («засмеялась и нежно укусила его за ухо»). Подобное сочетание смягчает прескриптивную категоричность, что вполне уместно для гармоничного коммуникативного поведения супругов.

Итак, инициирующий коммуникативный ход представляет собой тактический прием речевой деятельности, когда адресант вводит тему общения, представляющую интерес для него и, возможно, для партнера, реализуя тем самым адекватную стратегическую цель. Именно данная стратегическая цель, предполагающая определенный характер речевого воздействия, может, по нашему мнению, служить основным критерием дифференциации коммуникативных ходов в аспекте проявления инициативы в общении. Представленная нами классификация разновидностей инициирующих коммуникативных ходов имеет достаточно условный характер. В процессе естественной коммуникации каждый коммуникативный ход функционально многообразен, и только абстрактное «препарирование» его позволит выделить доминантную интенцию и отнести к определенному виду. 


\section{Литература}

Бобырева Е.В. Семантика и прагматика инициальных и финальных реплик диалога: Автореф. дис. ... канд. филол. наук. Волгоград, 1996.

Иссерс О.С. Коммуникативные стратегии и тактики русской речи. М., 2006.

Леонтович О.А. Методы коммуникативных исследований. М., 2011.

Макаров М.Л. Основы теории дискурса. М., 2003.

Федорова Л.Л. Теория речевой коммуникации и грамматика диалога // Коммуникативные стратегии культуры и гуманитарные технологии: Науч.-метод. матер. / Рос. Гос. пед. ун-т им. А.И. Герцена. СПб., 2007. С. 103-135. 